\title{
MONITORING OF LANDSCAPE COMBINATIONS AND CONCOURSES IN THE HUNGARIAN DANUBE-BEND
}

\author{
Erzsébet Krisztina Csereklye \\ Szent István University, Department of Nature Conservation and Landscape Ecology, \\ 2103 Gödöllö, Páter K. u. 1., Hungary, e-mail: csereklye@gmail.com
}

Submitted 5 Jan. 2009; accepted 14 Jul. 2009

\begin{abstract}
In Hungarian Danube-bend the flora of the area is very diversified due to climatic factors. Numerous species of flora characteristic of the area are under protection. The Danube-bend and vicinity is one of the most well-known part of Hungary, rich in historical relics and in natural assets. The city of Vác occupies a central place in the Danube-Bend Region. Among Vác's attributes, we can find rare and invaluable cultural and historical values. The most significant natural attribute is the Grove of Vác near the Danube bank. The example of the Grove of Vác is of country-wide importance in many aspects - it is part of the Duna-Ipoly National Park - though local protection is reasonable regarding the treatment and links because of the pollution of the environment. The natural advantages are affected by air pollution due to the increased industrial, commercial, and economic life of the city. Nowadays, the research of environmental pollution comes to the front because of the importance of heavy metals in the landscape classification. Even though the heavy metals are a natural component of the environment, we have to look them toxic materials. This paper focuses on the pollution analysis I carried out with various plant samples. It shows the main toxicology pollutants present in different landscape combinations and concourses. In tree specie, like Salix alba, near the band of No. 2 motorway I observed 5-8 times more values as compared with samples from the Duna-Ipoly National Park and nearly all kinds of heavy metals was elevated in Plantago major. In the life of the ecosystem, the primary source of heavy metals is the No. 2 motorway and the secondary is the pollution of the Danube bank.
\end{abstract}

Keywords: Danube-bend, flora, Hungary, landscape ecology, pollution.

\section{Introduction}

Providing a harmonic relationship between society and environment, while improving the state of health of the population, must include preservation, improvement and restoration of the natural environment also necessary for proper quality of life. This includes providing the conditions of a healthy environment, by reduction and elimination of threatening impacts. Enforcement of environmental criteria in economic development must be maintained and economic growth must lead to increasing population welfare accompanied with decreasing environmental burden.

The preconditions are the development and maintenance of a harmonic relationship between society and environment in the course of economic development, through a balance of sustainable natural resources and land use. Use of the environment must not exceed its load-bearing capacity. Prevention, and the mitigation to the smallest possible extent, of environmental damage (Máthé 2005).

Natural and semi-natural areas and habitats should not be considered as strictly divided islands or "reserves", but as unified and connecting systems. An ecological network is a coherent, functioning system, in which communication is active between natural habitats. Patches of habitats - with greater than a critical size - are the core areas. Their size is critical because they provide habitat and genetic reserve for the most possible populations among the given conditions. Communication between the core areas is realised by the so-called ecological corridors. Ecological corridors are linear, continuous habitats, or habitat-chains with smaller or greater interruptions (Pallag 2000).

Although each species has its own specific requirement for habitat size and mobility, there is often considerable scope for adapting the physical form of a corridor. One must take into account both the needs of the target species and the characteristics of local human activities. For example, corridors need not always be continuous linear pathways. Certain kinds of less intensively used landscape or so-called "stepping stones" of smaller landscape elements - such as ponds, sometimes provide the appropriate degree of interconnectivity. It is also important to recognise that various kinds of land use may be compatible with the function of a corridor and considerable flexibility may be possible in deciding a corridor's route and dimensions (Tardy 2002).

Nowadays the evaluation of heavy metal pollutant levels on the landscape is gaining importance. Although heavy metals are natural components of the environment, we have to consider them potentially toxic materials (Szöke 2005).

The negative effect of heavy metals and other potentially hazardous trace elements is observed in different environmental compartments: atmosphere, surface and 
underground air, water and soil (Pasieczna 2003; Möller et al. 2005; Norra et al. 2006; Zhang 2006; Jankauskaitè et al. 2008) especially in the cities and industrial areas. According to predictions based on research monitoring changes in the metal concentrations in the soil and plants, heavy metals will probably become important environmental stress factors over the next decades (Pais 1992).

\section{Method}

The outstanding natural assets of the Danube-bend and vicinity were basically formed as a result of more factors. From the point of view of botanical and zoological range of species, the Danube-bend lies on the boundary of lowland, alpine, and medium-height mountains (according to certain theories several lowland plant species spreaded to the south from here). Therefore flatland, as well as medium-height mountain associations and species can be found in its flora and fauna. The mosaic of these provides chances for survival for dozens of valuable species. The other powerful factor is the extremely varied superficial forms of mountains and riverbanks, which - in small, closed habitats - can provide essential conditions for communities accommodated to them. Finally, because of these characteristic steep canyons and mountain sides, small hidden marshes, the area is defended also from uninitiated intruders, from people who take nature as prey. Besides all these, the most captivating aspect of the region - also for visitors spending only a short time here - is the amazing sight of the Danube-bend, this unique landscape, which enframes the assets that can be found here (DINP 2007). Natural environs reminiscent of the original, natural conditions here can only be found in patches, but some of these are rather precious. The protected areas can be divided in to two main parts: the wet associations of river banks and the dry lawn associations of the interior of the island.

The wet areas - strips along the bank, peninsulas, little nearby islets, puddles, very short dead branches of the Danube, small sandbanks - are located mainly north of the road connecting Tahitótfalu and the ferry at Vác and at the southern part of the island off Szentendre. Broomwillow-poplar groves, willows in stagnant water constitute larger and smaller patches at these areas. The avifauna of the area is rather rich, more than fifty species nest on the island. Littoral birds, ducks, cormorants (Phalacrocorax carbo), common herons, great white herons, the kingfisher are quite common. Guests from the North mergansers (Mergus $s p$ ) and several species of the diving ducks populate the bank. At the left bank of the Danube it is best to cycle to look at it, as there is a well built bicycle path all along the river from Dunakeszi to Szob. In the narrow strip - wider at places - the vegetation is similar to that of the Szentendre Island (willow-poplar groves, smaller broom-willow and alder patches, puddly willows of abandoned construction pits). There are peninsulas, smaller islands in the strip along the river often covered with very dense forest. With a bit of luck iris or snowflake (Leucojum vernum) can also be spotted. The avifauna of the area is similar to that of listed at the
Szentendre Island. In Vác (in the Grove of Vác) it is worth walking along on the educational path, where associations and species of flood areas can be studied by the aid of notice-boards (DINP 2007).

The scientific investigation and analyses: With current encroachment and arrangement of development, the Danube Bend Region and its areas demonstrates that the fast, regionally uncoordinated, often accidental growth and pollution of settlement areas reduces proportionally the green areas, as well as the proportion of the biologically active surfaces. Beyond this, it endamages the ecological balance and reduces the prospects of the long term exploitation of the favourable conditions of the particular areas. The decrease of the biologically active forests, plough-lands, meadow-lands, grazing lands, and the spontaneous building up of the territories changes the character of the land, often reducing the development potential of a bigger area. This process leads to the depreciation of the territories. As a result of the environmental pollution arising from the human carelessness and ignorance, the maintenance and restoration of the natural state becomes more difficult, and the demands of the society, especially of the local population, must be taken into consideration during its management (Aradi 1999). The green areas do not appear on the territory of the region in a homogeneous way, and the reduction of the extent of the forests is significant.

The decrease of the biologically active surfaces can be registered especially on the periphery of the settlements, and can be characterized by the increasing proportion of intensive agriculture, new construction in territories or location of territories selected for construction, as the main part of the new build-ups is performed on such territories. Territories under national or local protection are the only exceptions. The reduction of the biologically active surfaces is a result of the territorial tans-ratings or new build-ups arising from the increased demands for settlement areas and green-field projects. The growth of the cultivation territories such as gardens, meadow-lands and plough-lands comes at the price of green surfaces. This can be attributed to change in the structure of the agriculture and the appearance of new proprietary interests (Fogarasi 2001).

The protection of the ecosystem, the consideration of the principle of sustainable development, the preservation of vital natural resources (water, land, air) for the future generations, and the implementation of economical and value-protecting management with attention to quantitative and qualitative characteristics in the management of natural resources; furthermore, safeguarding natural systems and natural resources, ensuring their survival, preservation of the diversity of the biosphere, and preservation of information inherent in natural processes (Máthé 2005).

Urban air pollution from road transport is a growing concern in a large number of developing country cities. With rising income, the use of motorized transport is expected to continue to increase in the coming years, potentially worsening the air quality (Vaitiekūnas 2007). Various substances are emitted to the air with traffic. 
A portion of these substances quickly form deposits on roads and the surrounding ground. Pollution along roads is the highest within the first few metres then becomes relatively low at a distance of 20 metres, although a measurable amount of whirled dust can get as far as 1000 metres from the road. The amount and spread of dust basically depends on the soil type, vegetation, the speed of vehicles, wind and moisture conditions. Large amounts of dust can be deposited on the vegetation along roads (Pallag 2000).

In many countries of the world one of the most important questions is a rational usage of natural resources and environmental protection from different-origin pollutants, damaging not only to the environment, but to humans as well (Baltrènas et al. 2004; Baltrènas and Zagorskis 2008) and that human activities were making negative effect on the climate's change too (Gimbutaite and Venckus 2008). In industries, such as chemical, lacquer and paints, oil reprocessing and food, there are many organic compounds which in different ways get into the atmosphere. Emitting volatile organic compounds cause formation which has an adverse effect on human health, flora and the environment in general (Baltrenas et al. 2004; Jeong et al. 2006; Laškova et al. 2007; Baltrènas and Zagorskis 2008).

Vascular plants, as well as mosses and lichens, are widely used in biomonitoring studies to explore and evaluate urban or industrial pollution. Biomonitoring with lichens or plants is a very useful and fruitful way to explore urban pollution. It has been developed worldwide in recent decades and it spans a lot of pollutants, including air pollutants and trace metals (Kim and Fergusson 1994; Riga-Karandinos and Karandinos 1998; Zimmerman et al. 2000; Bates et al. 2001; Conti and Cecchetti 2001; Garty 2001; Ballach et al. 2002). Key in identifying good biomonitors (phytomonitors) of the urban pollution is to use the proper plants for the special meteorological conditions of each town or area. For example, drought tolerant for hot and dry seasons which are too long. Then the proper time of sampling must be determined to obtain more accurate information (RigaKarandinos et al. 2002).

Urban and industrial pollution results in the deposit of metals on plants in cities, suburbs and forests. Thus, in biomonitoring procedures, the analyses of the plant leaves allow for the determination of the concentrations of accumulated metals and aid in the indirect assessment of the type of pollution in cities and industrial areas (Riga-Karandinos and Saitanis 2004).

Although only some tree species (e.g. willows and osiers) are considered to be suitable for effective uptake of metals, there is a growing demand to use a wide range of tree species as a part of an integrated management of soil reclamation and forest regeneration following sewage sludge amendment (Pulford and Dickinson 2005; French et al. 2006; Baltrénaitè and Butkus 2007). The uptake of trace metals by trees is a complex process and its efficiency varies with different tree species, the soil properties $(\mathrm{pH}$, redox potential, particle size and organic matter content), substrate conditions, sewage sludge age, metal content, metal availability, etc (Butkus et al. 2002; Katinas et al. 2002; Puford and Dickinson 2005; French et al. 2006). The low levels and the narrow range of the concentrations of all the metals on the new leaves did not allow the determination of any reliable correlations between metal concentrations and traffic load (RigaKarandinos and Saitanis 2004).

\section{Study area}

The examined territory is located in Danube-bend Region in Pest County on the southern boundary of the interior of Vác, partly on the periphery of the town (Fig. 1). Phitogeographically, it is a part of the Nógrád flora district within the Great Plain flora region. It is contiguous with the Nógrád flora district of the Hungarian mountains to the east and north. The border of the city includes the main part of Naszály, where conditions are close to natural, and indigenous vegetation appears in some places.

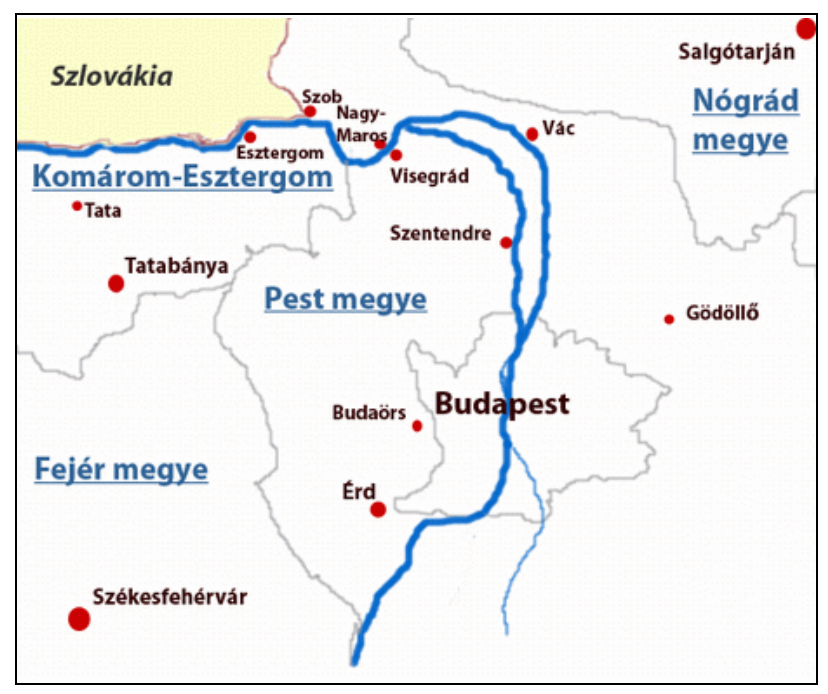

Fig. 1. Danube-bend Region in Pest County

The flora of the area is much diversified due to climatic factors. Numerous species of flora characteristic (Bánhidi 2001; Bíró 2002) of the area are under protection. The flora of the protected territories is well-known all over the country. Similar to the flora, the fauna of the water, waterside, forest, meadow and highland is diversified. Numerous protected waterside bird species, as well as species of fish, amphibians and reptiles can be found in the protected natural territories, in the Grove of Vác (Fig. 2), which is situated on the southern part of Vác (Bíró 2002).

The Grove of Vác has three owners: the Catholic Church, the local government and the Hungarian State. The maintenance, development and defence of the Grove of Vác are carried out by these three entities. It is significant that in the examined territory one can find different conservationist organisations and networks: the DanubeIpoly National Park, territories with Natura2000, the Cross-Country Ecological Network, as well as territories declared protected by the local government (VKF 2001; VPHI 2005). 


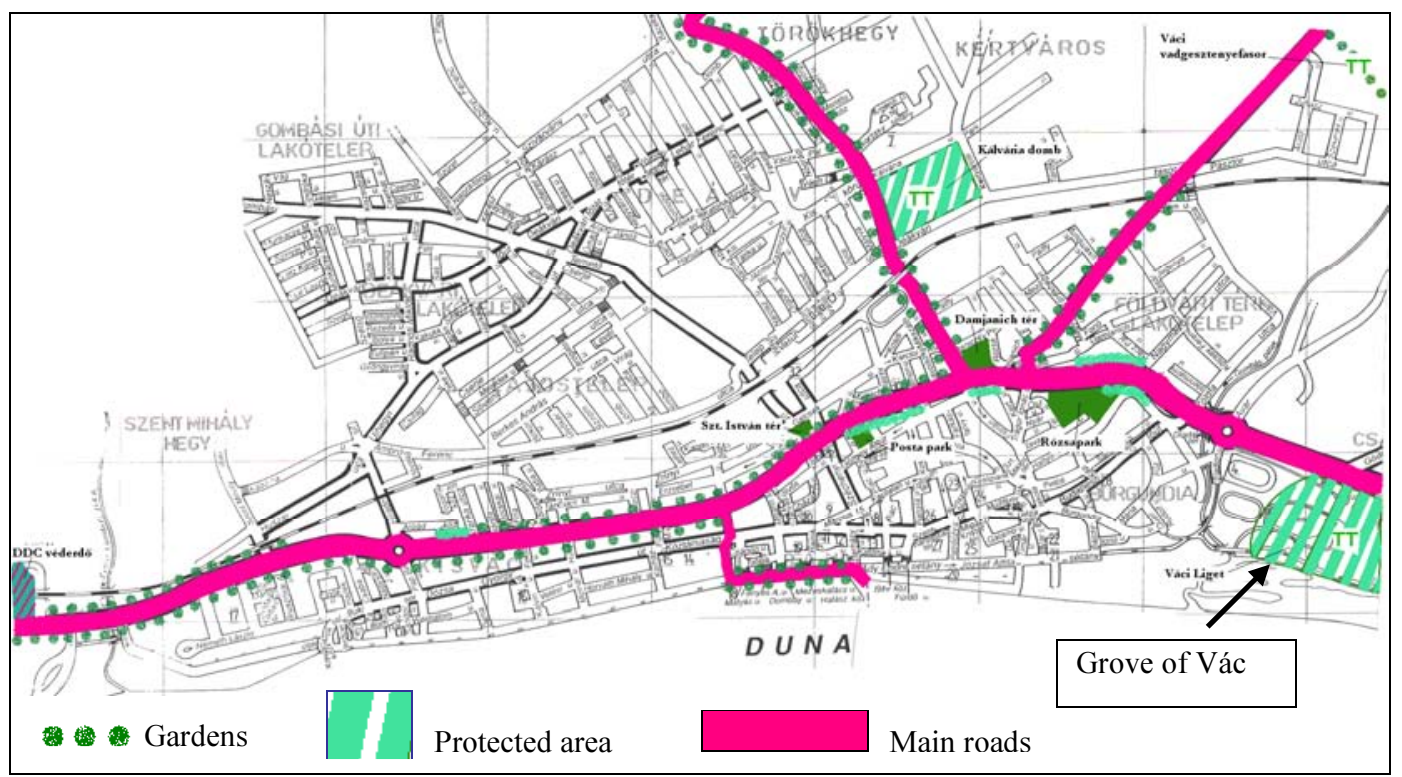

Fig. 2. Map of the study area in city of Vác

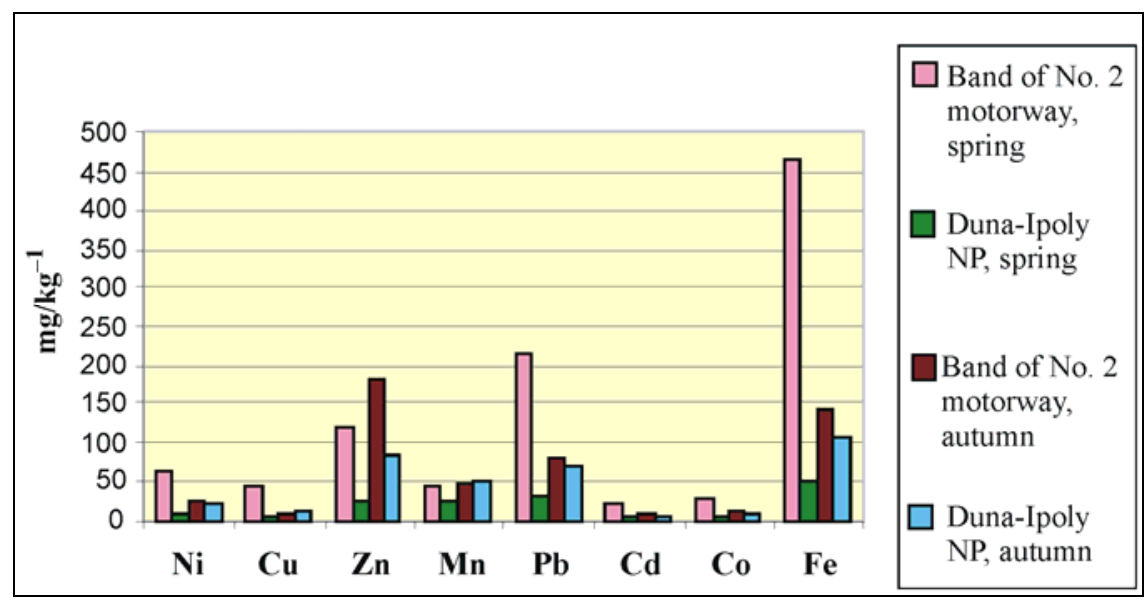

Fig. 3. Spring and autumn toxicological pollution of Salix alba in the Grove of Vác (data from 2007)

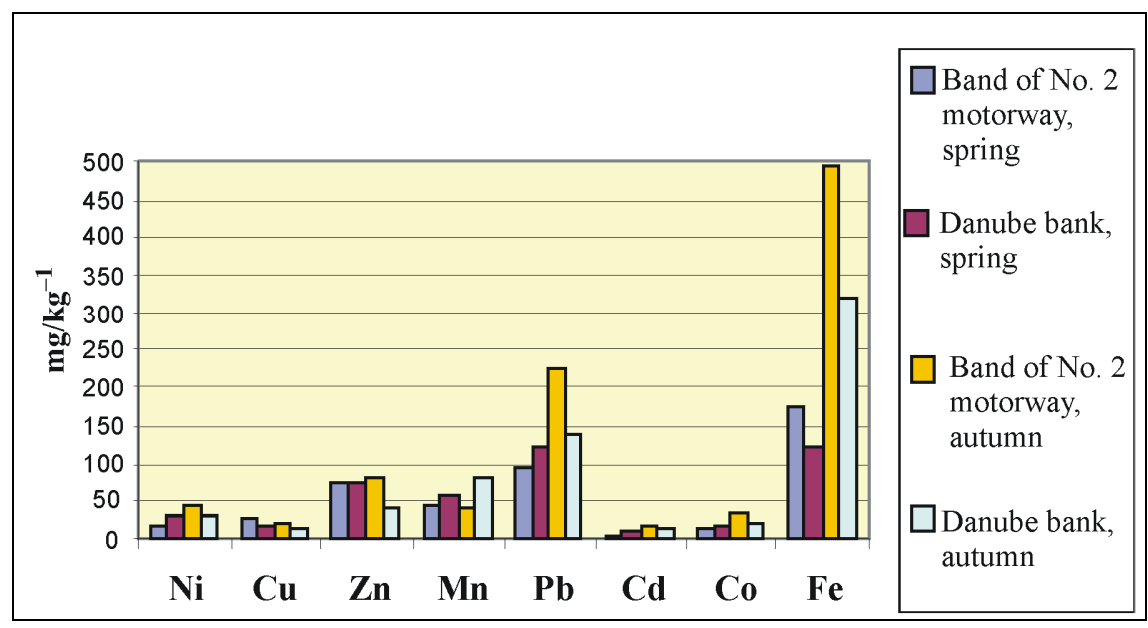

Fig. 4. Spring and autumn toxicological pollution of Plantago major in the Grove of Vác (data from 2007) 
The fact is that, in this little region, we meet with a broad spectrum of diverse ecosystems which embraces the significant inland water types: spring, brook, lake, marsh, flood plain and river (Horváth 1998, 1999).

Based on the analyses, the problems lie not only in delineating the river-system of Grove of Vác, but also they touch on its other individual aspects (cultural history, land aesthetic) (Sápi 1983; Bánhidi 2001).

I conducted the data collection for toxicological pollution in three units in the Grove of Vác, which is a mosaic ecosystem. After our study these will be evaluated against the function of land use types, ecosystem facilities and conflicts between the different landscape uses.

The first ecosystem unit was the natural ecology along the Danube River bank. The second unit was a planted band (verge) adjacent to the No. 2 motorway. The third unit was a transition field between the areas of the natural plants and the disturbed plants by the motorway. I made the data collection for plant toxicological pollution in these areas and I compared these with sample plants from the Duna-Ipoly National Park as controls.

Among the analysed plant pieces, we can find more trees, for example Fraxinus excelsior, Salix alba and bushes Buddleia davidii, Ligustrum ovalifolium, Pyracantha coccinea, Syringa vulgaris, Spiraea vanhouttei and in the herb Plantago major.

\section{Results and discussion}

I analysed the following elements in the sample leaves: $\mathrm{Ni}, \mathrm{Cu}, \mathrm{Zn}, \mathrm{Mn}, \mathrm{Pb}, \mathrm{Cd}, \mathrm{Co}, \mathrm{Fe}$. Plant samples were collected in two periods: the first in early May and the second at the end of October.

All plant samples were cut into small pieces, dried at $70{ }^{\circ} \mathrm{C}$ and ground to a fine powder in order to pass a $0,5 \mathrm{~mm}$ aperture screen. The destruction of organic matter was accomplished by dry ashing $0,5 \mathrm{~g}$ of plant material in a muffle furnace at $500{ }^{\circ} \mathrm{C}$ for 8 hours. The ash was dissolved in dilute $\mathrm{HNO}_{3}$ filtered and diluted with deionized water to a final volume of $25 \mathrm{ml}$.

All metal concentrations were determined by atomic absorption spectrophotometry. The calibration standards were prepared in the same matrix used for the plant samples. At all stages of sample preparation and analysis, stringent precautions were taken to minimize contamination from air, glassware, etc and analytical grade reagents were used. A control sample was analyzed for every 10 samples and reproducibility was tested by reanalyzing $30 \%$ of the samples. The analytical precision, measured as relative standard deviation, was less than $5 \%$. Concentrations of the metals in plant material were expressed as $\mathrm{mg} \mathrm{kg}^{-1}$ dry plant weight.

Based on our analytical outcomes, it is concluded that, on the Danube bank and the band along No. 2 motorway, an exceptional toxicology level has evolved in the vegetation. In some tree species, like Salix alba, near the band of No. 2 motorway - appearing in all spring and autumn samples - I observed multiple values as compared with samples from the Duna-Ipoly National Park (Fig. 3). These values occasionally could be as much as 5-8 times as concentrated. Furthermore, the content of nearly all kinds of heavy metals was elevated in Plantago major, in the autumn samples from the areas along No. 2 motorway and the Danube bank (Fig. 4, 5). This suggests that the heavy metals have a very important function in the life of the Grove of Vác. In the life of the ecosystem, the primary source of heavy metals is the No. 2 motorway and the secondary is the pollution of the Danube bank.

These values occasionally could be as much as $5-8$ times as concentrated. Furthermore, the content of nearly all kinds of heavy metals was elevated in Plantago major, in the autumn samples from the areas along No. 2 motorway and the Danube bank (Fig. 4, 5). This suggests that the heavy metals have a very important function in the life of the Grove of Vác. In the life of the ecosystem, the primary source of heavy metals is the No. 2 motorway and the secondary is the pollution of the Danube bank.

\section{Discussion}

Human health is essentially influenced by air quality. Atmospheric air in residential areas contains many pollutants. It follows that changes in species composition in the natural and transition bands could change the composition throughout the Grove of Vác, with impact on landscape use methods and potential influence on the micro climate, too.

These are just preliminary results and provide information about the actual stage. It is absolutely necessary to continue the investigation of the plant pieces.

This examination could be a part of a complex research which aims to analyse the heavy metal pollution of Grove of Vác (plants, soil, and water-systems: springs, lake, stream, river).

Typically, the plantation of new forests goes on in such territories where the owner of the territory shows his intention concerning it, and the territory is also deemed suitable for this purpose. Arising from this, the regional interests and the interests of land use of the area are emphasized less, and a lack of ideas and accordance characterize the process.

If the pollution of the plants, soil, and the watersystem prove to be interrelated, it outlines a future environmental protection duty for landscape management. The monitoring and the plain publishing of the measured values are important both for the authorities and the public.

\section{Conclusions}

1. The air pollution of Vác has increased to such an extent that it also reaches the agricultural and natural territories. Besides the effect on humans, the pernicious effect on plants and animals also appears more and more. The plants are often very responsive to air pollution, therefore the lichens can be used as indicators. The extent of the impairment depends on the concentration of the contaminant, the duration of the effect, as well as the species, type, and age of the plant, which, if taken into consideration, renders the effect acute or lingering.

2. External signs cannot be observed in the case of lingering impacts. The number of individuals and species decreases in the natural population. Actual deserts of 


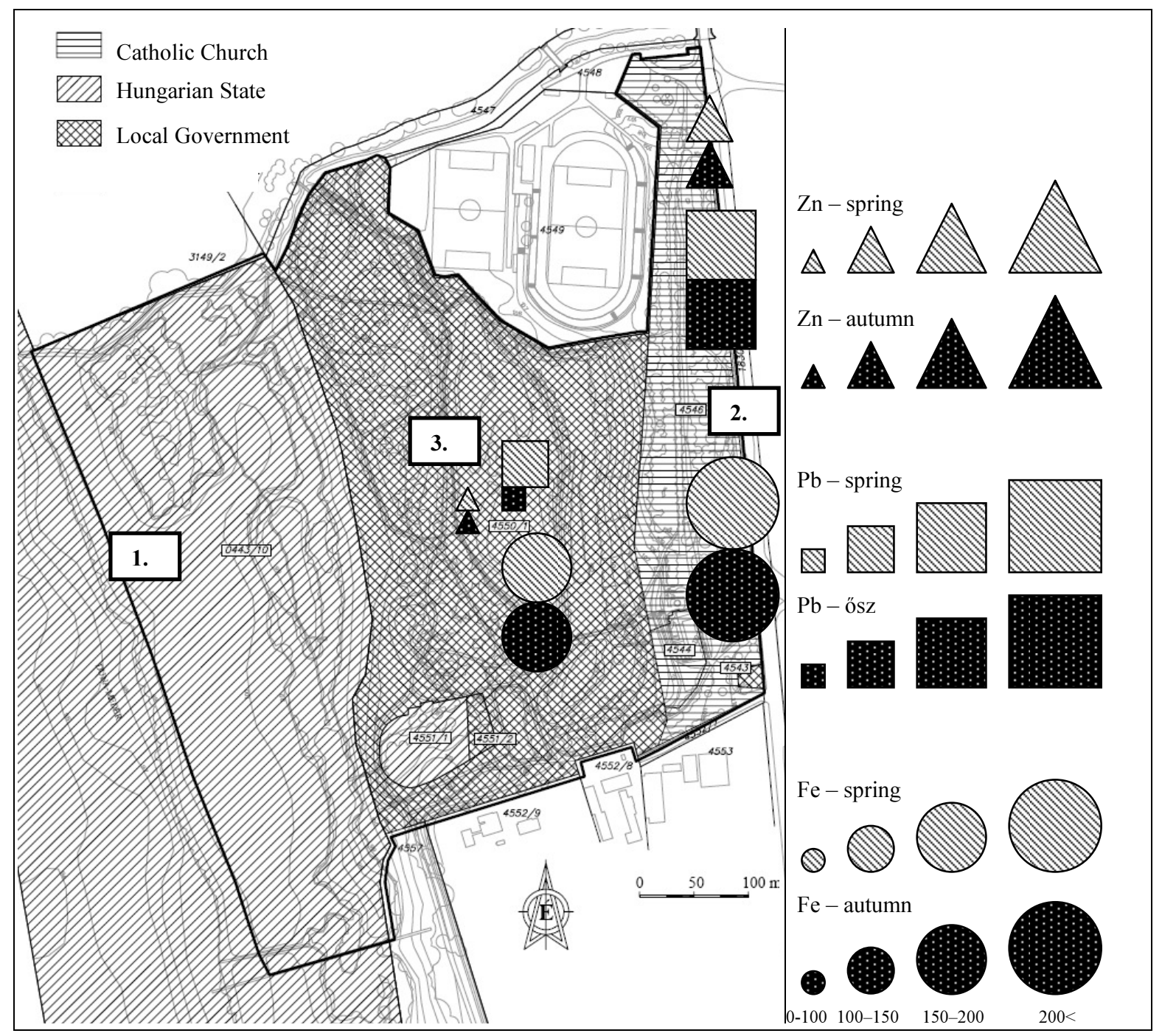

Fig. 5. The concentration of zinc, lead and iron in the leaves samples in the three types ecosystem $\left(\mathrm{mg} / \mathrm{kg}^{-1}\right)$

lichens emerge in the polluted areas. The multiplication of resistant, mostly valueless, species changes the composition of the coenosis. The degenerative disease of the forests has been a growing problem since the 1980s; the air pollution also contributed to its emergence.

3. The new green surfaces appear mostly in isolated, disintegrated territories, and typically not in those areas where the interests of the Danube-bend should require green surfaces. Nonetheless, we cannot deny that the appearance of new forests in the Danube-bend is a positive feature, even if the territorial distribution is not always suitable.

4. The heavy metals have a very important function in the life of the Grove of Vác. In tree specie, like Salix alba, near the band of No. 2 motorway I observed 5-8 times more values as compared with samples from the Duna-Ipoly National Park and nearly all kinds of heavy metals was elevated in Plantago major. In the life of the ecosystem, the primary source of heavy metals is the No. 2 motorway and the secondary is the pollution of the Danube bank.

\section{References}

Ballach, H.; Wittig, R.; Wulff, S. 2002. Twenty-five years of biomonitoring lead in the Frankfurt/Main area, Environmental Science and Pollution Research 2: 136-142. doi:10.1007/BF02987461

Baltrènaite, E.; Butkus, D. 2007. Modelling of $\mathrm{Cu}, \mathrm{Ni}, \mathrm{Zn}, \mathrm{Mn}$ and $\mathrm{Pb}$ transport form soil to seedlings of coniferous and leafy trees, Journal of Environmental Engineering and Landscape Management 15(4): 200-207.

Baltrènas, P.; Zigmontienè, A.; Vaiškūnaite, R. 2004. Oro valymo biotechnologijos [Biotechnology of air purification]. Vilnius: Technika. 205 p.

Baltrenas, P; Zagorskis, A. 2008. Investigation of cleaning efficiency of biological air-treatment device with activated charge of different origin, Journal of Environmental Engineering and Landscape Management 16(3): 113-120. doi:10.3846/1648-6897.2008.16.113-120

Bánhidi, L. 2001. A XXI. század küszöbén: Vác [Close to the XXI. Century: Vác]. CEBA Kiadó, Budapest.

Bates, J. W.; Bell, J. N. B.; Massara, A. C. 2001. Loss of Lecanora conizaeoides and other fluctuations of epiphytes on oak in S. E. England over 21 years with declining SO2 concentrations, Atmos. Environ. 35: 2557-2568. doi:10.1016/S1352-2310(00)00402-7 
Bíró, Gy. 2000. Vác Város Városfejlesztési- és Környezetvédelmi állapotfelvétel [Monitoring of City Development and Environmental Protection of Vác], Vác Város Önkormányzata [The Govenment of City of Vác], 2-6.

Bíró, I. 2002. Váci Kistérség környezeti, illetve levegőtisztasági állapotának vizsgálata [Environmental and air pollution monitoring of Small Region of Vác], Aragon-Art Bt., 540.

Butkus, D.; Baltrènaite, E.; Kaziukonienė, D. 2002. Estimation of heavy metal accumulation in tree rings, Environmental Engineering [Aplinkos inžinerija] X(4): 156-160.

Conti, M. E.; Cecchetti, G. 2001. Biological monitoring: lichens as bioindicators of air pollution assessment - a review, Environ. Poll. 114: 471-492. doi:10.1016/S0269-7491(00)00224-4

Duna-Ipoly Nemzeti Park 2007. Fedezze fel a Duna-Ipoly Nemzeti Parkot! [Explore the Duna-Ipoly National Park] Duna-Ipoly Nemzeti Park Igazgatósága, Budapest.

French, CH. J.; Dickinson, N. M.; Putwain, PH. D. 2006. Woody biomass phytoremediation of contaminated brownfield land, Environmental Pollution 141: 387-395. doi:10.1016/j.envpol.2005.08.065

Fogarasi, Gy. 2001. A Közép-Magyarországi Régió Struktúraterve [Central Hungarian Region Structural Plan], Pro Régió Ügynökség, Budapest, 80-83.

Garty, J. 2001. Biomonitoring atmospheric heavy metals with lichens: theory and application, Crit. Rev. Plant Sci. 20(4): 309-371. doi:10.1016/S0735-2689(01)80040-X

Gimbutaite, I.; Venckus, Z. 2008. Air pollution burning different kinds of wood in small power boilers, Journal of Environmental Engineering and Landscape Management 16(2): 97-103. doi:10.3846/1648-6897.2008.16.97-103

Horváth, B. 1998. A Váci-ligeti-tó és környezetének ökológiai funkcióinak feltárása, rehabilitációs javaslata [Monitoring and rehabilitation possibilities of the Lake of the Grove of Vác]. Teampannon, Miskolc.

Horváth, B. 1999. A Ligeti-tó vizrendszere vizminőségi és ökológiai állapot vizsgálata [Water-system analysing and ecological monitoring of the Lake of the Grove]. Teampannon, Miskolc.

Illyés, Zs. 2005. Váci-Liget természetvédelmi kezelési és rehabilitációs terve [Environmental usage and rehabilitation plan of the Grove of Vác]. BCE, Tájvédelmi és Tájrehabilitációs Tanszék, Pagony Táj és Kertépítész Iroda, Budapest.

Jankauskaite, M; Taraškevičius, R; Zinkutè, R; Veteikis, D. 2008. Relationship between landscape self-regulation potential and topsoil additive contamination by trace elements in Vilnius city, Journal of Environmental Engineering and Landscape Management 16(1): 5-14. doi:10.3846/1648-6897.2008.16.5-14

Jeong, E.; Hirai, M.; Shoda, M. 2006. Removal of p-Xylene with Pseudomonas sp. NBM21 in Biofilter, Journal of Bioscience and Bioengineering 102(4): 281-287. doi:10.1263/jbb.102.281

Katinas, V., et al. 2002. Processes of chemical element dispersion and redistribution in environment using wastewater sludge for recultivation of woodcuttings areas, Geologija 38: 3-11.

Kim, D. N.; Fergusson, E. J. 1994. Seasonal variations in the concentrations of Cadmium, Copper, Lead and Zinc in leaves of the horse chestnut (Aesculus hippocastanum L.), Environmental Pollution 86: 89-97. doi:10.1016/0269-7491(94)90010-8
Laškova, T.; Zabukas, V.; Vaitiekūnas, P. 2007. Meteorologiniu sąlygu itaka lakiuju organiniu junginių sklaidai pažemès atmosferos sluoksnyje [Influence of meteorological conditions on volatile organic compound spread in the atmospheric boundary layer], Journal of Environmental Engineering and Landscape Management 15(3): 135-143.

Máthé, L. 2005. Questionnaire for the assessment of the national policy, legal and institutional frameworks related to the Carpathian convention. Department of Environmental Policy and Science, Central European University, Budapest.

Möller, A.; Muller, H. W.; Abdullah, A.; Abdelgawad, G. and Utermann, J. 2005. Urban soil pollution in Damascus, Syria: concentrations and patterns of heavy metals in the soils of the Damascus Ghouta, Geoderma 124(1-2): 6371. doi:10.1016/j.geoderma.2004.04.003

Norra, S.; Lanka-Panditha, M.; Kramar, U. and Stuben, D. 2006. Mineralogical and geochemical patterns of urban surface soils, the example of Pforzheim, Germany, Applied Geochemistry 21(12): 2064-2081. doi:10.1016/j.apgeochem.2006.06.014

Pais, I. 1992. Az általánosan létfontosságú mikroelemek [Essencially microelements]. Budapest.

Pallag, O. (Ed.). 2000. The effect of linear infrastructures on habitat fragmentation. COST 341. Hungarian State of the Art Report, European Commission Directorate General Transport, Technical and Information Services on National Roads (ÁKMI), Budapest.

Pasieczna, A. 2003. Atlas of urban soils contamination in Poland. Polish Geological Institute, Warsaw. 83 p.

Pulford, I. D.; Dickinson, N. M. 2005. Phytoremediation technologies using trees, in Trace Elements in the Environment: Biogeochemistry, Biotechnology and Bioremediation. M. N. V. Prasad, Kenneth S. Sajwan, Ravi Naidu (Eds.), CRC, 375-395.

Riga-Karandinos, A. N.; Karandinos, M. G. 1998. Assessment of air pollution from a lignite power plant in the plain of Megalopolis (Greece) using as biomonitors three species of lichens; impacts on some biochemical parameters of lichens, The Science of the Total Environment 215: 167183. doi:10.1016/S0048-9697(98)00119-3

Riga-Karandinos, A. N.; Saitanis, C.; Paxinou, H. 2002. Seasonal variations in the concentration of trace metals in leaves of laurel, used as bioindicator of urban traffic pollution in Athens, in $8^{\text {th }}$ FECS Conference 2002.

Riga-Karandinos, A. N.; Saitanis, C. 2004. Biomonitoring of concentrations of platinum group elements and their correlations to other metals, Int. J. Environment and Pollution 22(5): 563-579. doi:10.1504/IJEP.2004.005910

Sápi, V. 1983. Vác története I-II. kötet [History of Vác part III]. Kiadta a Pest Megyei Múz. Ig., Szentendre, 12-15.

Szőke, E. 2005. Research on the heavy metal pollution of some cave waters of the karsts of Aggtelek from 2000 until now, Acta Climatologia et Chorologica, Univer. Szegediensis, Tom. 38-39: 135-142.

Tardy, J. (Ed.). 2002. Progress report on the establishment of the National Ecological Network in Hungary. Nature Conservation, Ministry of Environment, Budapest.

Váci Körzeti Földhivatal [Regional Land Registry Office of Vác] 2001, Föösszesitö [Main cumulative].

Vaitiekūnas, P.; Banaitytè, R. 2007. Modeling of motor transport exhaust pollutant dispersion, Journal of Environmental Engineering and Landscape Management 15(1): $39-46$. 
Vác Polgármesteri Hivatal Irattár [Record Office of Government of Vác]. 2005. A Váci-liget Természetvédelmi Kezelési és Felújitási Terve [The Environmental Protection and Development Project of Grove of Vác]. Vác Város Önkormányzata [The Govenment of City of Vác].

Zhang, C. 2006. Using multivariate analyses and GIS to identify pollutants and their spatial patterns in urban soils in Gal- way, Ireland, Environmental Pollution 142(3): 501-511. doi:10.1016/j.envpol.2005.10.028

Zimmermann, R. D.; Wagner, G.; Finck, M. 2000. Guidelines for the use of biological monitors in air pollution control (plants). WHO Collaborating Centre for Air Quality Management and Air Pollution Control, Berlin, Germany.

\section{APLINKOS TARŠOS ITAKOS KRAŠTOVAIZDŽIUI DUNOJAUS VINGYJE VENGRIJOJE MONITORINGAS}

\section{E. K. Csereklye}

Santrauka

Vengrijoje Dunojaus vingyje augalija dèl klimatinių veiksnių yra labai įvairi. Dauguma teritorijai būdingų augalijos rūšių saugomos. Dunojaus vingis ir apylinkès - viena iš geriausiai Vengrijoje žinomų vietų, turtingų istorinių relikvijų ir gamtos vertybių. Vacas (Vác) - miestas, išsidėstęs centrinėje Dunojaus vingio regiono dalyje. Miestas turi retų ir neikainojamų kultūrinių ir istorinių vertybių. Reikšmingiausias natūralusis jo bruožas yra Vaco giraitẻ šalia Dunojaus kranto. Ji kraštui svarbi daugeliu aspektų - tai dalis Duna-Ipoly nacionalinio parko. Čia taikoma vietiné apsauga, pagrista tvarkymu stebint aplinkos tarša, kuri daugiausiai pasireškia oro tarša dèl pramonès, komercinès ir ekonominès veiklos mieste. Siais laikais aplinkos taršos tyrimai tampa vis aktualesni dẻl besikaupiančių sunkiujų metalų. Net jei sunkiujų metalų šaltiniai gamtiniai, reikia stebėti, kad koncentracijos neviršytų leidžiamųjų. Straipsnyje taršos analizė pateikiama įvairių augalų tyrimų pavyzdžiais. Tiriant medžius Salix alba, augančius šalia greitkelio Nr. 2 ruožo, buvo nustatytos 5-8 kartus didesnės teršalų koncentracijos, palyginti su nustatytomis Duna-Ipoly nacionaliniame parke. Beveik visų sunkiųjų metalų koncentracijos buvo didesnès Plantago major. Tiriant ekosistemas nustatyta, kad pirminis sunkiųju metalų šaltinis yra greitkelis Nr. 2, su tuo susijusi Dunojaus vingio tarša.

Reikšminiai žodžiai: Dunojaus vingis, augalija, Vengrija, kraštovaizdžio ekologija, tarša.

\section{МОНИТОРИНГ ВЛИЯНИЯ ЗАГРЯЗНЕНИЯ ОКРУЖАЮЩЕЙ СРЕДЫ НА ЛАНДШАФТ В ИЗГИБЕ ДУНАЯ В ВЕНГРИИ}

\section{Э. К. Чэрекйэ}

Резюме

Флора региона в изгибе Дуная в Венгрии весьма разнообразна в связи с климатическими факторами. Многие виды флоры, характерные для данной области, находятся под охраной. Этот регион является одним из наиболее известных в Венгрии. Он богат историческими реликвиями и природными достопримечательностями. Город Вац (Vác) занимает центральное место в регионе. Большое культурное и историческое значение присуще многим его достопримечательностям. Наиболее велико в природном отношении значение рощи в городе Вац на берегу Дуная. Роща города важна не только для края, но и для всей страны во многих отношениях. Это часть национального парка, значение которого неоценимо в связи с защитой окружающей среды от загрязнений, выделяемых промышленными, коммерческими и другими предприятиями. В настоящее время исследования загрязнения окружающей среды становятся все актуальнее в связи с необходимостью классифицировать тяжелые металлы по их воздействию на ландшафт. Даже тяжелые металлы, являющиеся естественным компонентом окружающей среды, могут расцениваться как токсичные элементы. В статье основное внимание уделяется анализу загрязнителей на примере их воздействия на разные растения. Проанализировано токсическое воздействие загрязнителей в разных их сочетаниях и в связи с особенностями ландшафта. В коре деревьев (Salix Alba), находящихся на участке вблизи скоростной автомагистрали № 2, было зафиксировано загрязнение металлами, в 5-8 раз превышающее подобные значения в национальном парке Дунай-Ипель. В жизни экосистемы первичным источником тяжелых металлов является автомагистраль № 2 и вторичным - загрязнения берегов Дуная.

Ключевые слова: изгиб Дуная, флора, Венгрия, ландшафтная экология, загрязнение окружающей среды.

Erzsébet Krisztina CSEREKLYE. Master of Agricultural and Environmental Landscape Management Engineering, 2006. Doctoral student, (environmental sciences), SZIU, since 2006. Publications: 5 research papers. Conferences: 13 conferences. Research interest: ecology, environmental protection. 